\title{
Religious evil: the basic issues
}

\begin{abstract}
Religious evil is evil caused or justified by religious beliefs or institutions. Religious evil is a significant issue both in applied ethics and in the philosophy of religion; in the latter area, it grounds a distinctive atheistic argument from evil. The two aspects of religious evil are interrelated in the sense that one's solution to the atheistic argument from religious evil predisposes one to specific approaches to the ethical problem of religious evil. The paper surveys the relevant literature and potential theistic defenses.
\end{abstract}

Religious evil is evil apparently caused by religious beliefs or institutions. The phrase can be used in two senses, narrow and wide. Before defining them, however, it is important to indicate what "evil" means in the present context.

"Evil" is used in at least two senses in the literature on the problem of evil. Sometimes it is used very generally to mean bad things (e.g. Van Inwagen 2006: 4), at other times, and almost invariably when particular cases of evil are discussed, it is used to refer to extreme forms of cruelty and suffering (e.g. van Inwagen 2006: 97, Russell 1989: 123). ${ }^{1}$ This paper aims at a conception that lies somewhere in between. Following a hint by Hazlett (2012: 27), I define evils as acts or practices that significantly harm the

\footnotetext{
${ }^{1}$ There is a growing literature on the nature of evil in moral philosophy, see e.g. Russell (2014) and The Concept of Evil special issue (Midwest Studies 36). That literature typically focuses on horrors: e.g. Card (2002: 20) links evil to "culpable intention to do someone intolerable harm," Garrard and McNaughton (2012) associate evil with moral horror, Russell (2014: 2) defines evil in terms of moral extremity, and Singer (2004: 193) defines it in terms of horrendous wrongness. As indicated later in the main text, non-horrendous but considerably bad practices (e.g. the persecution of sexual minorities) are just as significant in the present context, so a horror-oriented conception of evil is less suitable here. For a specific clash between such conceptions and the present one, see Scarre (2012: 88), who classifies socially harmful proselytizing as not evil.
} 
well-being of individuals or social groups. On this conception, horrors (e.g. genocides) qualify as evils, but so does political or economic oppression, the persecution of minorities, or any sort of violent conflict in general. The reason for adopting this relatively liberal conception of evil is purely pragmatic: it covers the cases that are routinely cited in the literature and in public discourse as evidence that religion (or certain forms of it) are harmful.

Using such a general conception of evil, religious evil in the narrow sense comprises evils committed in the name of some deity or supernatural principle. These evils are portrayed by their perpetrators, or by the religious authorities that the latter deem legitimate, as sanctioned or even explicitly called for by the higher powers. The crusades and witch hunts are paradigm examples.

In the wide sense of the phrase, a religious evil is any evil that results from the abuse of religious authority, whether or not the evil in question can be portrayed as conforming to the divine will. Pedophilia in the clergy is a phenomenon that fits the wide but not the narrow conception of religious evil.

Religious evil is an important issue for three reasons. First, it is a staple of contemporary anti-religious rhetoric. The figureheads of 'New Atheism' routinely portray religion as inherently irrational because of religious evil, as shown by the opening passage of Richard Dawkins's atheistic magnum opus:

Imagine, with John Lennon, a world with no religion. Imagine no suicide bombers, no 9/11, no 7/7, no Crusades, no witch-hunts, no Gunpowder Plot, no Indian partition, no Israeli/Palestinian wars, no Serb/Croat/Muslim massacres, no persecution of Jews as 'Christ-killers', no Northern Ireland 'troubles', no 'honour killings.' [...] Imagine no Taliban to blow up ancient statues, no public beheadings of blasphemers, no flogging of female skin for the crime of showing an inch of it. (Dawkins 2006: 1-2, cf. Harris 2003: Ch. 1, Hitchens 2007: 15-36) 
More to the point, religious evil looms large in two areas of philosophy. It is an important topic in applied ethics where philosophers (together with historians, theologians, psychologists, and social scientists) are debating the nature and provenance of religious evil and the best policy responses to it. Religious evil is, in addition, important for the philosophy of religion as yet another potential challenge to the tenability of theism. Although these two aspects of religious evil are closely related, they are conceptually distinct. For convenience, let's call them "the practical aspect" (= religious evil as a topic in applied ethics) and "the theoretical aspect" (= religious evil as a topic in the philosophy of religion).

The literature on the practical aspect is quite extensive, especially since 2001 . The literature on the theoretical aspect, as far as the present author knows, is virtually nonexistent. This is lamentable because, as we will see, religious evil grounds a distinctive atheistic argument which is importantly different from the traditional arguments from evil. One potential reason for this neglect might be that, from those theistic standpoints that are openly represented in the academia, it might seem obvious that perpetrators of religious evil are not truly religious and therefore what I call "religious evil" is not an issue about theism proper. But, as we'll see, this fact (if it is a fact) is itself part of the problem of religious evil.

Since there are excellent surveys about the practical aspect of religious evil and the allied empirical issues (Clarke 2014: Ch. 8, Kitts et al. 2013, Murphy 2011), I only give some pointers to the relevant literature in Section 1, mostly in order to support the claim that some forms of evil appear to be endemic to religion. The bulk of the paper focuses on the theoretical aspect. Section 2 constructs an atheistic argument from religious evil and it considers possible ways to refute it. In Section 3, I address the connection between the practical and the theoretical aspects. 


\section{The facts of religious evil}

It is undeniable that violence is a persistent part of the history of religion. As Alcorta and Sosis (2013: 571) remark, "archaeological and ethnographic evidence suggests that violence and conflict with outsiders has been a central element of religion since its emergence in human evolution." Indeed, violence seems endemic to religion in the sense that religious traditions and texts appear to inspire violence regularly and with great effectiveness. Abdallah Azzam, the mentor of Osama bin Laden, wrote: "History does not write its lines except with blood. Glory does not build its lofty edifices except with skulls" (Cook 2013: 232).

Although Islamic terrorism is perhaps the best known and most problematic form of religious violence today, all major religious traditions have inspired and justified violence (see e.g. the "Overview" section in Juergensmeyer et al. 2013). In the case of Christianity, the standard examples are the crusades and witch hunts (see e.g. Allen and Amt 2003 and Levack 2013, respectively, for details). But it is important to see that the crusades and witch hints were not isolated incidents, wholly alien to the spirit of Christian institutions. No major Christian church is pacifist except for small denominations such as the Mennonite church, the Quakers, the Amish, and the Church of the Brethren (Clarke 2014: 101). The only consistently peaceful Christian communities are the Coptic, Armenian, Syrian Orthodox churches (Kimball 2013: 429, 432). Although some contemporary Christian thinkers have argued for pacifism (Hauerwas 1984, Yoder 1994), others have weighed in against it (Niebuhr 2011 [1940]), and there is a long tradition of just war theory in Christian theology (see Clarke 2014: Ch.4 for an overview; see Johnson 1997: 52-3 for Aquinas's endorsement of war 
against heretics and sinners). "For much of its history," Steve Clarke (2014: 118) tells us, "the Catholic Church has considered it to be justifiable to act violently towards heretics - those who develop revisions of officially prescribed religious dogma - as well as apostates - those who abandon their religion." Aquinas opined that heretics deserve to be executed (Summa II 2 q11 art3), and Duns Scotus taught that the forced conversion of Jews is morally justified (Turner 2006: 195-6, Krop 1989: 165). Calvin argued that it is a duty of Christian leaders to kill blasphemers (Wendel 1963: 97). A late offshoot of this tradition is Pastor Michael Bray's book, A Time to Kill (1994), which explains that the killing of abortionists is "justifiable homicide" (Jefferis 2011: 54-8). These ideas have actually been put to practice: at least 8 physicians have been killed by anti-abortionists since 1991 (Clarke 2014: 164), and throughout history, Christians have been known to torture and persecute heretics, blacks, Jews, and other non-Christians (King 2013: 296, Gaddis 2005, Mathews 2008). ${ }^{3}$

Such phenomena are not unique to Christianity, of course. Islam, Judaism, Hinduism, and Sikhism all have their just war traditions (Clarke 2014: 95), and it would not be hard to find examples of similar treatment of heretics and dissenters. Even Buddhism, which is often seen as the odd man out in debates about religion, has its own tradition of justifying violence. Tibetan lamas praised the acts of both Ghengis Khan and Gushri Khan (Jerryson 2013: 56, Maher 2010), and the 6th-century Buddhist cult leader Faqiq advocated killing as a path toward becoming a boddhisatva (Demiéville

\footnotetext{
${ }^{2}$ Sometimes, these ideas were put into practice by the clergy itself. Ten German bishops fell in battle in the late 800s (Kimball 2013: 427) and the archbishop of Mainz claimed to have killed nine people on the battlefield (Bainton 1960: 104). A more recent manifestation of the Christian just war tradition was the Catholic clergy's support of the Vietnam War (Clarke 2014: 90).

${ }^{3}$ Note, also, that some forms of Christianity appear to predispose parents toward corporal punishment on scriptural grounds (Wiehe 1990).
} 
2010). Buddhist scholars have claimed that killing and torture can have positive karmic consequences for the victims (Jenkins 2010: 67-70), and the current Dalai Lama believes that that "wrathful coercive action," if motivated by compassion, is not a form of violence (Jenkins 2011).

These facts are, arguably, strong evidence that violent tendencies are either intrinsic to, or can be very effectively channeled by, religion. Clarke $(2014: 7,107-10)$ argues that religion opens up additional conceptual resources for justifying evil, and, given an appropriate apocalyptic or dualistic ideology, it can justify almost any form of violence. Particularly severe cases are the mass killings perpetrated by the Aum Shinrikyo sect in Japan and the mass suicides organized by Heaven's Gate, the Peoples Temple, and other sects (Partridge 2008, Sells 2013). The causal role of religion in violence will be revisited in $\$ 2.1$ below.

Religion has been accused of various forms of nonviolent evil as well. Many of the case studies referenced above can be construed as evidence that religion fosters intolerance toward alternative belief systems. Such intolerance, under appropriate circumstances, can seriously harm the well-being of social groups even in the absence of violence, hence it can qualify as a nonviolent form of evil.

A less severe but often repeated charge is that religion systematically hinders or hindered intellectual progress. To name just one example, Carl Sagan wrote that "for a long time, the human instinct to understand was thwarted by facile religious explanations" (1983: 184). Since scientific knowledge contributes heavily to the wellbeing of society, hindering scientific progress qualifies as a nonviolent form of evil.

However, such alleged nonviolent forms of religious evil are hard to validate, because the causal role of religion in the phenomena at hand is highly contentious. For example, in the case of the influence of religion on scientific progress, Robert Merton 
(1968) used sociological data to argue that Protestantism was instrumental in bringing about modern science, and Paul Feyerabend (1993: 54-146) claimed that the religious authorities in Galileo's time were perfectly rational to reject Galileo's theory simply because it rested on flimsy empirical evidence. The charge that religion fosters xenophobia, homophobia, political or economic oppression etc. are similarly hard to substantiate, and, as far as the present author knows, there are no systematic empirical studies on these issues. So, for the purposes of the rest of this essay, "religious evil" will refer to violent forms of religious evil, because these have been extensively documented and studied and their reality is undeniable.

My next goal is to explore the significance of religious evil in the philosophy of religion, where it (arguably) grounds a distinctive argument for atheism. Since the current literature on the problem of evil focuses almost exclusively on monotheism of the broadly Judeo-Christian-Muslim kind, "religion" from now on refers to that type of belief (called "theism" for short).

\section{The problem of religious evil (PRE)}

Religious evil is prima facie evidence that belief in God causes evil. But, intuitively, a morally perfect God who loves humans and wants to bring them into harmony with himself would make it certain that religion does not cause evil. The problem of religious evil (PRE) is the challenge to explain, on theistic grounds, why a morally perfect, omnipotent God would create a world where religious evil exists. More analytically, one can set up the following atheistic argument from religious evil: ${ }^{4}$

(1) Belief in God causes evil.

(2) If God exists, then God wants us to believe in God.

\footnotetext{
${ }^{4}$ This is a simplified version of the argument in Kodaj (2014: 428).
} 
(3) If God exists, then God does not want us to do anything that causes evil.

(4) Therefore, by (1) and (3), if God exists, then God does not want us to believe in God.

(5) Therefore, by (2) and (4), God does not exist.

The argument is valid. Although it has the form of a reductio, it is an evidential, as opposed to logical, argument from evil: the premises are not meant to be unassailable facts but propositions with a high degree of credence. As we saw in $\S 1$, there is reason to think that religion facilitates evil, so (1) appears to be true, while (2) and (3) are highly plausible given the traditional conception of God as a supernatural being who promotes belief in himself and dissuades his creatures from immoral behaviour .

The argument has three premises, (1)-(3). The theist can, in principle, deny any of them. The following subsections look at the resulting defenses, highlighting their connection to contemporary work on the problem of evil.

\subsection{Denying (1)}

(1) Belief in God causes evil.

In conversation, theists sometimes react to (1) by claiming that atheism also causes evil (witness Nazism or Stalinism). Presumably, this move is meant to take the sting of PRE away by portraying humans as equally prone to commit horrible things regardless of their beliefs about the supernatural. (Variants of this strategy include the claim that atheism leads to more evil than religion, hence the alternative to theism is even worse, and the claim that religion, in the final reckoning, causes more good than evil, hence it is not that bad, overall.) But even if it were true that atheism also causes evil (or that atheism causes more evil than theism etc.), that is wholly irrelevant in the context of 
PRE. If (1), (2), and (3) are true, then theism is false. Measuring religious evil against the evils caused by atheism and/or to the good that religion otherwise brings does not refute any of the premises.

Premise (1) can be denied in three ways: (i) by claiming that religious evil seems to be evil to the uninitiated but it is, in fact, good ("the Fundamentalist Defense"), (ii) by accepting that the perpetrators of religious evil are theists but denying that their theistic beliefs are causally relevant for their acts ("the Epiphenomenalist Defense"), (iii) by denying that perpetrators of religious evil are truly religious ("the False Believers Defense").

The Fundamentalist Defense is unlikely to appeal to any reasonable theist, although some prominent Christian philosophers have flirted with it. For example, Eleonore Stump writes:

The deliberate infliction of serious physical or psychological suffering is only the genus of torture, not its species. Many things that are morally good and worthy of prizing fall within that same genus. [...] When [the motivations] have to do only with love, or at least with an overriding desire for the well-being of the sufferer, there is no torture. [...] To be willing to inflict suffering out of care for the sufferer is ennobling, not corrupting. (Stump 2011: 206-7)

A few similar responses will be quoted and assessed in $\$ 2.3$ below.

The Epiphenomenalist Defense rests on an empirical claim, the claim that religious beliefs are not among the causes of religious evil. This thesis is quite controversial. As we saw, Clarke (2014) argues that religion provides additional conceptual resources for justifying violence. Avalos $(2005,2013)$ claims that religion is based on creating scarce symbolic resources, guaranteeing conflict and violence. A number of other scholars agree that religion is intrinsically violent (Juergensmeyer 2003, Schwartz 1997, 
Wellman and Tokuno 2004). Others argue that religion is only a pretext for violence and not a cause of it (Cavanaugh 2009, Jacobs 2003, Ward 2006). (In the specific context of Islamic terrorism, Lincoln (2003) and Ignatieff (2004) argue for a distinctively religious provenance while Pape (2005) and Goodin (2006) claim that the underlying causes are purely political.)

However, it is important to see that even if the Epiphenomenalist Defense had solid empirical support, it would not really solve PRE, because it implies that true faith is unable to stop people from committing some of the worst sins. ${ }^{5}$ As a result, the atheist can rebuild the argument using the Epiphenomenalist Defense plus the premise that if God existed, God would make it sure that true faith stops people from sinning in the worst possible ways. The theist only can resist this new premise by claiming that God does not want to stop true believers from sinning, which leads to a variant of the Fundamentalist Defense that will be addressed in $\$ 2.3$ below.

On the False Believers Defense, premise (1) is false because terrorists, witch hunters etc. are not truly religious. (See Sacks 2015 for a defense of this type.) This is, again, a highly controversial empirical claim, since perpetrators of religious evil often appear to be very devout, they hold the same religious texts as sacred etc. But even if one could find a definition of "religion" on which people who commit evils in the name of God are not religious, this would not solve PRE, because the argument can be restated using the premise that if God existed, God would make sure that revelation cannot be misinterpreted in such horrible ways by false believers, giving rise to seemingly devout travesties of true religion. To fend off this new premise, the theist must explain why God cannot or will not prevent those perverted forms of religion.

\footnotetext{
${ }^{5}$ There might be empirical evidence for the inefficacy of religion in preventing immoral behaviour: Argyle (1958: 96-9) claims that criminal behaviour is not negatively correlated with religious belief.
} 


\subsection{Denying (2)}

(2) If God exists, then God wants us to believe in God.

One can deny (2) by claiming that being a monotheist is not an objective moral duty: it is at best a supererogatory activity, one that everyone is free to refrain from, and many people (viz. potential perpetrators of religious evil) should refrain from. (I'm assuming that it is an objective moral duty to $\varphi$ iff God wants us to $\varphi$.) Call this "the Pluralist Defense." The gist of the Pluralist Defense is that humans are under no obligation to be monotheists as opposed to being Hindus, Buddhists, or atheists.

The Pluralist Defense appears to be contrary to the spirit of extant forms of theism. Historically, theists strongly believed that praising God is a universal moral duty (cf. Aquinas' and Calvin's claim, referenced in $\S 1$, that heretics deserve to be executed). They also believed that non-theists will be damned or at least will have significant difficulties getting into heaven. Assuming that entry into heaven signals that one's sins are forgivable while being denied entry indicates that they are not, the doctrine at hand implies that those who do not worship God are less virtuous. Admittedly, these historical tenets are less prevalent today: the Second Vatican Council (1962-65) shifted to what Clarke (2012) calls a "salvific preferentialist" position on which atheists and members of other religions can also be saved, and reasonable theists nowadays do not question the legal right to be a non-theist. Still, it seems fair to say that practicing theists typically do not defend openly and vigorously the claim that worshipping God is not a real moral duty.

Moreover, denying (2) is not enough to solve the challenge of religious evil, because the denial creates a residual problem as long as (1) and (3) are left in place. If God does not want us to believe in God yet God does not want us to do anything that causes evil either and belief in God causes evil, then why did God allow religion to 
exist in the first place? Intuitively, the best divine strategy in such a case is to hide from humans completely, making it practically impossible for them to invent religion.

The Pluralist Defense therefore must be complemented with extra premises. A suggestion is found in Kodaj (2014: 437-42), who argues that God has sufficient reason to permit religious evil if (i) being religious is not a moral duty (therefore (2) is false), (ii) perpetrators of religious evil are not truly religious (i.e. the False Believers Defense is true and hence (1) is false as well), (iii) God has sufficient independent reason to permit some evil, and (iv) God wants us to realize that (i) is true, that is, God wants us to know that praising God has no moral value in itself and is much less important, morally speaking, than preventing evils like rape, torture, murder, and war. Because of (iii), this defense presupposes a prior solution to the traditional problem of evil.

\subsection{Denying (3)}

(3) If God exists, then God does not want us to do anything that causes evil.

Like (2), this premise borrows strong prima facie support from the theistic tradition, a dominant theme of which is God's care for our moral education. A sane deity who wants his children to be moral can hardly want them to engage in activites that cause evil. Or so one would think.

Premise (3) can be resisted (without giving up (2), the claim that being religious is a moral duty) by claiming that God wants some true believers to commit certain evils. A number of prominent theistic philosophers, including St. Augustine, Alvin Plantinga, and Richard Swinburne, endorse or respect this idea:

One should not think it a horrible cruelty that Joshua did not leave anyone alive in those cities that fell to him, for God himself had ordered this. However, whoever for this reason thinks that God himself must be 
cruel and does not wish to believe that the true God was the author of the Old Testament judges as perversely about the works of God as he does about the sins of human beings. (Augustine 2005: 67)

Maybe death as such isn't as horrifying as we ordinarily think. [...] [W]e all die anyway, we are all under a death sentence; how bad is it to die earlier rather than later? And, on the other side: how bad is the moral and spiritual corruption, blasphemy, infant sacrifice, temple prostitution, and the like attributed to the Canaanites? Maybe it is worse, even much worse, than we think. [...] Considerations such as these are perfectly sensible, and have been what millions of Christians have taken to be no more than the sober truth. (Plantinga 2011: 111, cf. Swinburne 2011: 233)

These passages hover between two strategies, the denial of (1), hinting at a contextualist theory of the moral worth of theists' actions (in special circumstances, e.g. when theists are killing Caananites, killing is good), and the denial of (3), with the underlying claim that evil (when perpetrated by true believers) is sometimes necessary (even though bad) because it serves some higher good.

A sophisticated way to pursue this kind of strategy is to reach for an infamous tool in Leibniz's theological toolbox:

[God] permits the dissonance [i.e. evil], not reluctantly but willingly, yet nevertheless per accidens, i.e., not on account of its own nature, but because by its occurrence a greater perfection exists in the whole. Thus God tolerates and permits sins, not reluctantly; nevertheless, he wills them per accidens because he knows that the series will be more perfect with these included and compensated for in a marvelous way. (Leibniz 2005: 129) 
Following Leibniz, the theist can make a difference between what God wills on account of its own nature and what God wills per accidens, with religious atrocities falling into the latter category. The formal upshot of this strategy is that "want" is not univocal in premises (2) and (3): God wants religiosity on account of its own nature and God wants religious evil per accidens. Call this the model of Warranted Theistic Violence (WTV). (I am not implying that Leibniz himself subscribed to WTV.)

Even if the central tenet of WTV were true and so killing, raping etc. in God's name were sometimes endorsed by God, the problem of religious evil would not be solved thereby. Without some independent explanation of why God would want any evil per accidens, the move is merely verbal. So WTV must be conjoined with some independent defense or theodicy that explains this. But that is still insufficient, because even if one explains why God would want any evil per accidens, one needs an additional explanation of why God would want any religious evil per accidens. ${ }^{6}$ Even if evil is an indispensable part of the divine plan, why didn't God arranged things so that unbelievers are the perpetrators and true religion is not defaced?

Whatever one's reply to this question, it is hard to see how a solution that denies (1) or (3) can fail to presuppose a doctrine of denominational moral exclusivism, the thesis that true believers fall under different moral laws than others, either because "it's not evil if the theist does it" (as the Fundamentalist Defense says) or because theists are sometimes required to perpetrate evil to further God's purposes (as the model of Warranted Theistic Violence implies). The chief problem with both strategies is that denominational moral exclusivism is precisely the kind of principle that appears to be the driving force behind religious violence. If true believers are justified to think that

\footnotetext{
${ }^{6}$ See Kodaj (2014: 432-7) on the difficulties of deploying extant theistic responses to the problem of evil to explain religious evil.
} 
they fall under different moral laws than the rest of us, that they are permitted to commit atrocities from time to time, then, provided that they are justified to think that they are true believers, they are also justified to think that they are permitted to commit atrocities. And given that one obvious effect of religious practice is that it confers prima facie warrant on the believer's conviction that she is a true believer, denominational moral exclusivism sounds like a recipe for more religious evil.

To drive this point home, consider the following passage by William Alston on the epistemology of violent and apocalyptic divine messages:

James Jones reports that God told him that it is His will that all the members of Jones's sect commit suicide. God, according to Jones, gives no reason for this. Since it seems very unlikely, given the account of the nature, purposes, and pattern of activity of God in the Christian tradition, that God would command any such thing, we (almost everyone in the mainline Christian community who considers the matter) reject the claim. Smith reports that God told him that the world will end on July 14,1977 , and that he and his fellow sect members should make certain preparations for this. Since this claim does not tie into anything else in the tradition and since many such claims have been empirically disconfirmed, it should be rejected. (Alston 1991: 190)

The problem with this seemingly straightforward criterion for discrediting purported calls for religious evil is that violence is part of the mainline Christian tradition, along with stories about God commanding violence. If Christians ought always to follow the tradition, then Alston's criterion is not a recipe against religious evil but an implicit endorsement of denominational moral exclusivism, with the majority of Christians serving as the privileged community. 
To sum up, the prospects of both the Fundamentalist Defnese and the model of Warranted Theistic Violence are quite dim. They presuppose a form of denominational moral exclusivism that seems impossible to defend.

\section{The two aspects of religious evil}

I began the paper by distinguishing between the practical aspect of religious evil (how religious evil figures in applied ethics) and its theoretical aspect (how it impacts the philosophy of religion). Although these aspects are conceptually distinct, they are nonetheless closely related in the following sense: One's stance on the theoretical aspect disposes one toward specific stances on the practical aspect.

If the argument from religious evil is sound, then theism is demonstrably false and hence there is one more reason to think that the solution to the practical issues is to undermine religion (see e.g. Avalos 2013: 566-7). If the Epiphenomenal Defense is correct, then religious evil is not a genuinely religious phenomenon but has underlying social and political causes and must be addressed accordingly (as e.g. Cavanaugh 2009, Goodin 2006, Jacobs 2003, Pape 2005, Ward 2006 urge). If the False Believers defense is correct, then solving the practical problem of religious evil depends on understanding and communicating the essential difference between true and false forms of religion (Sacks 2015). If the Pluralist Defense is correct, then a key component in solving the practical problems might be promoting religious diversity (including atheism) from within religion. And if the Fundamentalist Defense or the model of Warranted Theistic Violence is correct, then the proper solution to the practical issue is to give power to the morally privileged religious denomination.

We saw, however, that none of these defenses works by itself — each must be complemented with further theories (including an adequate response to the traditional 
problem of evil). It would be interesting to know how a potential complete solution to the theoretical problem of religious evil interacts with the issues in applied ethics.

\section{References}

Alcorta, Candace S. and Richard Sosis (2013): Ritual, religion, and violence: An evolutionary perspective. In Juergensmeyer et al. 2013: 571-96.

Allen, S. J. and Emilie Amt (2003): The Crusades: A Reader. Broadview Press.

Alston, William P. (1991): Perceiving God. Cornell University Press.

Argyle, Michael (1958): Religious Behaviour. Routledge \& Kegan Paul.

Augustine (2005): Questions on Joshua 16. In John R. Franke (ed.), Ancient Christian Commentary on Scripture: Old Testament IV, Inter-Varsity Press.

Avalos, Hector (2005): Fighting Words: The Origins of Religious Violence. Prometheus Books.

- (2013): Religion and scarcity: A new theory for the role of religion in violence. In Juergensmeyer et al. 2013: 554-70.

Bainton, Roland H. (1960): Christian Attitudes toward War and Peace. Abingdon Press.

Bergmann, Michael, Michael J. Murray, Michael C. Rea (eds.) (2011): Divine evil? The Moral Character of the God of Abraham. Oxford University Press.

Card, Claudia (2002): The Atrocity Paradigm: A Theory of Evil. Oxford University Press.

Cavanaugh, William T. (2009): The Myth of Religious Violence. Oxford University Press.

Clarke, Steve (2012): Coercion, consequence and salvation. In Y. Nagasawa (ed.), Scientific Approaches to the Philosophy of Religion, Palgrave Macmillan, 205-23.

_ (2014): The Justification of Religious Violence. Wiley Blackwell.

Cook, David: Martyrdom in Islam. In Juergensmeyer et al. 2013: 226-41.

Dawkins, Richard (2006): The God Delusion. Houghton Mifflin. 
Demiéville, Paul (2010): Buddhism and war. In Jerryson and Juergensmeyer 2010: 1758.

Feyerabend, Paul (1993): Against Method (3rd ed.). Verso.

Gaddis, Michael (2005): There Is No Crime for Those Who Have Christ: Religious Violence in the Christian Roman Empire. University of California Press.

Garrard, Eve and David McNaughton (2012): Speak no evil? Midwest Studies in Philosophy 36, 1-17.

Goodin, Robert E. (2006): What'sWrong with Terrorism? Polity Press.

Harris, Sam (2004): The End of Faith: Religion, Terror, and the Future of Reason. W. W. Norton \& Company.

Hauerwas, Stanley (1984): Should War be Eliminated: Philosophical and Theological Investigations. Marquette University Press.

Hazlett, Allan (2012): Non-moral evil. Midwest Studies in Philosophy 36, 18-34.

Hitchens, Christopher (2007): God is not Great: How Religion Poisons Everything. Hachette Book Group.

Ignatieff, Michael (2004): The Lesser Evil: Political Ethics in an Age of Terror. Edinburgh University Press.

Jacobs, Alan (2003): Afterward. In K. R. Chase and A. Jacobs (eds.), Must Christianity Be Violent?, Brazos Press, 224-35.

Jefferis, Jennifer L. (2011): Armed for Life: the Army of God and Anti-abortion Terror in the United States. Praeger.

Jenkins, Stephen. (2010): Making Merit through Warfare According to the ÄryaBodhisattva-gocara-upāyavişaya-vikurvaņa-nirdeśa Sütra. In Jerryson and Juergensmeyer 2010: 59-75.

_ (2011): It's not so strange for a Buddhist to endorse killing. The Guardian, May 112011.

Jerryson, Michael (2013): Buddhist traditions and violence. In Juergensmeyer et al. 2013: 41-66 
Jerryson, Michael and Mark Juergensmeyer (eds) (2010): Buddhist Warfare. Oxford University Press.

Johnson, James Turner (1997): The Holy War Idea in Western and Islamic Traditions. Pennsylvania State University Press.

Juergensmeyer, Mark (2003): Terror in the Mind of God: The Global Rise of Religious Violence. University of California Press.

Juergensmeyer, Mark, Michael Jerryson, Margo Kitts (eds) (2013): The Oxford Handbook of Religion and Violence. Oxford University Press.

Kimball, Charles: Religion and violence from Christian theological perspective. In Juergensmeyer et al. 2013: 424-34.

King, Karen L. (2013): Christianity and torture. In Juergensmeyer et al. 2013: 293-305.

Kitts, Margo, Mark Juergensmeyer, Michael Jerryson (2013): Introduction: The enduring relationship of religion and violence. In Juergensmeyer et al. 2013: 1-12.

Kodaj, Daniel (2014): The problem of religious evil. Religious Studies 50: 4, 425-43.

Krop, Henri A. (1989): Duns Scotus and the Jews: Scholastic theology and enforced conversion in the thirteenth century. Nederlands Archief voor Kerkgeschiedenis 69: $161-75$.

Leibniz, G.W. (2005): Confessio Philosophi: Papers concerning the problem of evil, 1671-1678 (ed. and trans. Robert C. Sleigh, Jr.). Yale University Press.

Levack, Brian P. (2013): The Oxford Handbook of Witchcraft in Early Modern Europe and Colonial America. Oxford University Press.

Lincoln, Bruce (2003): Holy Terrors: Thinking about Religion after September 11. University of Chicago Press.

Maher, Derek F. (2010): Sacralized warfare: The fifth Dalai Lama and the discourse of religious violence. In Jerryson and Juergensmeyer 2010: 77-90.

Mathews, Donald G (2008): The Southern rite of human sacrifice: Lynching in the American South. Mississippi Quarterly 62: 27-70. 
Merton, Robert K. (1968): Puritanism, pietism, and science. In his Social Theory and Social Structure, The Free Press, 601-40.

Murphy, Andrew R. (2011): Introduction. In A. R. Murphy (ed.), The Blackwell Companion to Religion and Violence, Blackwell, 1-4.

Niebuhr, Reinhold (2011 [1940]): Why the Christian Church is not pacifist. In M. Juergensmeyer and M. Kitts (eds.), Princeton Readings in Religion and Violence, Princeton University Press, 45-54.

Pape, Robert A. (2005): Dying to Win: The Strategic Logic of Suicide Terrorism. Random House.

Partridge, Christopher (2008): The end is nigh: failed prophecy, apocalypticism, and the rationalization of violence in new religious eschatologies. In Walls 2008: 191212.

Plantinga, Alvin (2011): Comments on 'Satanic Verses' by Evan Fales. In Bergmann et al. 2011: 109-14.

Russell, Bruce (1989): The persistent problem of evil. Faith and Philosophy 6, 121-39.

Russell, Luke (2014): Evil: A Philosophical Investigation. Oxford University Press.

Sacks, Jonathan (2015): Not in God's Name: Confronting Religious Violence. Hodder \& Stoughton.

Sagan, Carl (1983): Cosmos. Abacus.

Scarre, Geoffrey (2012): Evil collectives. Midwest Studies in Philosophy 36, 74-92.

Schwartz, Regina (1997): The Curse of Cain: The Violent Legacy of Monotheism. University of Chicago Press.

Sells, Michael A. (2013): Armageddon in Christian, Sunni, and Shia Traditions. In Juergensmeyer et al. 2013: 467-95.

Singer, Marcus (2004): The concept of evil. Philosophy 79, 185-214.

Stump, Eleonore (2011): Reply to Draper. In Bergmann et al. 2011: 204-7.

Swinburne, Richard (2011): Reply to Morriston. Bergmann et al. 2011: 232-4. 
Turner, Nancy L. (2006): Jewish witness, forced conversion, and island living: John Duns Scotus on Jews and Judaism. In M. Frassetto (ed.), Christian Attitudes Toward the Jews in the Middle Ages: A Casebook, Routledge, 183-209.

van Inwagen, Peter (2006): The Problem of Evil. Clarendon Press.

Ward, Keith (2006): Is Religion Dangerous? Lion Hudson.

Walls, Jerry L. (ed.) (2008): The Oxford Handbook of Eschatology. Oxford University Press.

Wellman, James K., Jr. and Kyoto Tokuno (2004): Is religious violence inevitable? Journal for the Scientific Study of Religion 43, 291-6.

Wendel, Francois (1963): Calvin. Collins.

Wiehe, Vernon R. (1990): Religious influence on parental attitude toward the use of corporal punishment. Journal of Family Violence 5: 2, 173-86.

Yoder, John Howard (1994). The Politics of Jesus. Eerdmans. 